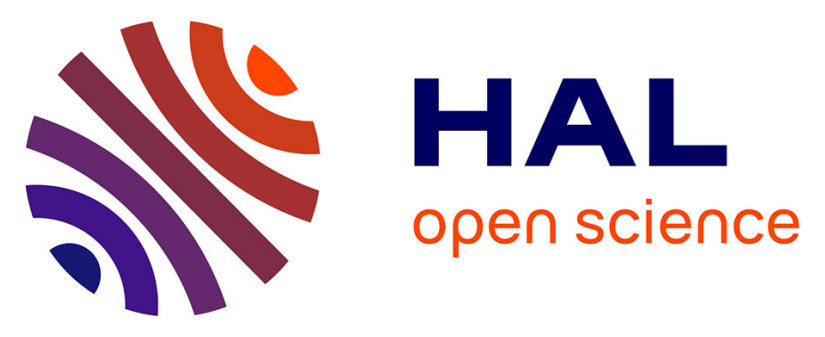

\title{
Partial Vertebrectomies without Instrumented Stabilization During En Bloc Resection of Primary Bronchogenic Carcinomas Invading the Spine: Feasibility Study and Results on Spine Balance
} Sam Ng, Julien Boetto, Gaëtan Poulen, Jean-Philippe Berthet, Charles Marty-Ané, Nicolas Lonjon

\section{To cite this version:}

Sam Ng, Julien Boetto, Gaëtan Poulen, Jean-Philippe Berthet, Charles Marty-Ané, et al.. Partial Vertebrectomies without Instrumented Stabilization During En Bloc Resection of Primary Bronchogenic Carcinomas Invading the Spine: Feasibility Study and Results on Spine Balance. World Neurosurgery, 2019, 122, pp.e1542-e1550. 10.1016/j.wneu.2018.11.098 . hal-02571390

\section{HAL Id: hal-02571390 \\ https://hal.umontpellier.fr/hal-02571390}

Submitted on 21 Oct 2021

HAL is a multi-disciplinary open access archive for the deposit and dissemination of scientific research documents, whether they are published or not. The documents may come from teaching and research institutions in France or abroad, or from public or private research centers.
L'archive ouverte pluridisciplinaire HAL, est destinée au dépôt et à la diffusion de documents scientifiques de niveau recherche, publiés ou non, émanant des établissements d'enseignement et de recherche français ou étrangers, des laboratoires publics ou privés.

\section{(ㄷ)(1) $\$$}

Distributed under a Creative Commons Attribution - NonCommerciall 4.0 International 
1 Partial vertebrectomies without instrumented stabilization during en bloc

\section{resection of primary bronchogenic carcinomas invading the spine:} feasibility study and results on spine balance

\section{$\underline{\text { Authors }}$}

Sam Ng ${ }^{(1)}$, Julien Boet to ${ }^{(1)}$, Ga ët a n Poul en ${ }^{(1)}$, Jean-Phil ippe Ber thet ${ }^{(2)}$, Char les Mart y-Ane ${ }^{(3)}$, Nicol as Lonjon ${ }^{(1,4)}$

(1) Department of Neurosurgery, Hôpit al Gui de Chauliac, Mont pell ier Univer sit y Medical Center, Mont pell ier, Fr ance

(2) Department of Thoracic surgery, Hôpit al Pasteur, Nice University Medical Cent er, Nice, Fr a nce

(3) Department of Thoracic surgery, Hôpital Arnaud de Villeneuve, Mont pel 1 ier Universit y Medical Center, Mont pell ier, France

(4) INSERM U1198, Univer sit y of Mont pellier, Fr a nce

\section{$\underline{\text { Key words }}$}

Primary bronchogenic carcinomas, Non-small-cell lung cancers, Lung cancers, Pancoast tumors, Vertebrectomies, Vertebral resection, Spine defor mit y

\section{$\underline{\text { Abbreviations and Acronyms }}$}

CCA: Cor on al Cobb angle

CT: Comput ed t omogr a phy

NSCLC: Non-small-cell 1 ung cancers

PBCIS: Primary bronchogenic carcinomas invading the spine

PET: Posit ron emission tomogr a phy 
27 SCAEOR: Sagit $\mathrm{tal}$ Cobb angle at the edge of the resection

28 SCA 1 1-T12: T1-T12 sagit t al Cobb angle

29 VB: Vertebral body

30

31 Abstract

32 Objective:

33 It is unknown if spinal instrument at ion is required to prevent deformit y 34 after partial vertebrectomy in the treatment of primary bronchogenic 35 carcinomas invading the spine (PBCIS). In this study, we focus on the 36 postoperative spine deformity in patients operated for partial vertebrectomies without instrumentation during en bloc PBCIS resection. Our objective was to determine if deformity depends on the type of vertebral resection and if any vertebral resection threshold can be observed to just if y additional spinal inst rument at ion.

41 Methods:

42 This is a retrospective study, including all patient s with PBCIS operated 43 without spinal instrumentation from 2009 to 2018. Partial 44 vertebrectomies were classified int o categories A, B and C depending on 45 vertebral resection. Patients had a long-term radiological follow-up 46 assessing the spine defor mit y evolution.

$47 \quad$ Results:

48 Eighteen patients were included. The median follow-up was 27 months. 49 Four patients underwent a secondary posterior instrumentation 50 surgical procedure due to progressive spinal deformity. A low-risk 
51 group of deformation was characterized as type A resection and type B

52 resection on less than threevertebrae.

53 Conclusion:

54 There are no validated criteria to justify a systematic spinal instrumentation when performing a partial vertebrectomy during en bloc resection of PBCIS. Performed al one wit hout spine inst rument at ion, both type A and type B resections on less than three resected vertebrae were not subject to sagit al and coronal deformity even after a long follow-up, emphasizing that a systematic stabilization is not needed in this low-risk group. These results could help to reduce the perioperative morbidity of these procedures that are usually long and compl ex.

(1)

\section{$\underline{\text { Text }}$}

\section{5}

\section{Introduction:}

7 Primary bronchogenic carcinomas invading the spine (PBCIS) are mainly

represented by non-small-cell lung cancers (NSCLC) ${ }^{1,2}$ located along

the costovertebral gutter. When invading the superior pulmonary

sulcustumors (Pancoast tumors), characterist ic sympt oms are complete

1 or partial Pancoast-Tobias syndrome. Invasion of the ribs, the vert ebrae

2 and the subclavian vessels causes pain in the shoulder area; invasion of

3 the lower part of the brachial plexus and invasion of the nerve roots

4 causes radicular pain or muscle weakness; and invasion of the stellate

5 ganglion and sympathetic chain is revealed by Horner syndrome ${ }^{3,4}$. 
76 Spinal invasion is commonly considered to be a negative prognostic

77 factor in primary bronchogenic carcinomas, making them historically

78 considered as incurable $e^{5}$. With the advances in the delivery of

79 chemotherapy, radiation and surgical management, carefully selected

80 patients with spine-invading NSCLC can be el igible to complete surgical

81 resection, allowing a major increase of survival ${ }^{6-8}$. Neoadjuvant

82 treatment with chemotherapy induction and concurrent radiation

83 followed by complete en bloc resection is now a standard treatment

84 option with demonstrated oncological results 9,10 . This procedure

85 usually requires thoracic and spine surgery teams and the

86 perioperative mortality rate remains high and varies from $9 \%$ to $58 \%{ }^{10-}$

87 12. A spinal instrumented stabilization is always performed when a

88 completevertebrectomy is required, increasing the mean operat ive time,

89 the blood losses and the postoperative morbidities. However, the

90 usefulness of a spinal instrumentation to prevent spine deformity has

91 not yet been assessed, especially concerning partial vertebrectomies. In

92 this study, we focused on the postoperative spine deformity in pat ients

93 operated with en bloc resection of PBCIS without instrumented

94 stabilization. The objective was to determine if a secondary spine

95 deformity depends on which type of vertebral resection was performed

96 and if any vertebral resection threshold can be observed to justify

97 additional spinal instrument at ion.

98

Patient s and Methods: 
100 This is a retrospective single-center study, including all patient s with

101 PBCIS operated from 2009 to 2018. Data were retrieved from the 102 electronic medical records. All patients underwent preoperative 103 neoadjuvant chemotherapy and radiation. Immediate preoperative spine 104 invasion was assessed with Weinstein, Boriani and Biagini ${ }^{13}$ (WBB) 105 st a ging (Figure 1) and the Spine Inst a bil it y Neopl a st ic Scor e ${ }^{14}$ (SINS) (Table 106 1). Both lung, chest wall resection and partial vertebrectomy were 107 performed during a single-stage procedure. Surgical approaches 108 included anterior cervico-thoracotomy $(n=1)$ and posterolateral 109 thoracotomy with extended incision to expose the spine $(n=17)$. No pat ient 110 underwent spinal instrument at ion during procedure.

\section{Surgical technique}

112 The patient is positioned in lateral position to expose the side invaded by 113 the tumor upwards (Shaw-Paulson approach). A posterolateral incision 114 passing below the tip of the scapula is performed. The scapula is then 115 mobilized laterally and superiorly after a careful dissection of the $116 \mathrm{tr}$ a pezius and $\mathrm{rhomboid}$ muscles. The penet $\mathrm{r}$ at ion int o the chest cavit $\mathrm{y}$ is 117 performed laterally to identify the tumor without violating its 118 margins. Intrathoracic procedure including lung, bronchus and 119 vascular dissection is performed by the thoracic surgeon. The incision is 120 then extended posteriorly to expose the affected vertebrae. Partial 121 vertebrectomies using osteotomes are then performed in the affected 122 levels. If the posterior vertebral elements are invaded, the $t$ umor is 123 isolated from the unaffected vertebra by performing a unilateral 124 laminectomy. The dura and nerve roots are then gradually exposed. 
125 Invaded nerve roots are clipped to prevent cerebrospinal fluid leakage 126 and cut. The osteotomy is extended to the vertebral body (VB). It is 127 performed medially to the ipsilateral pedicle, allowing a facet and 128 pedicle removal en bloc with the tumor. The invaded VB osteotomy is 129 performed through osteotomy and followed by the section of the 130 anterior longit udinal 1 igament. A safety margin is respected to avoid

131 any violation of the tumor. After removing the $\mathrm{t} u$ mor en bloc (Figure 2), 132 mediast inal 1 y mphadenect omy is per for med.

133 Spine balance analysis

134 Immediate post operative computed tomography (CT) scan were analysed 135 and compared to preoperative CT scan. We used the classification 136 described by Jain ${ }^{15}$ (Figure 3 and Figure 4) and created three groups 137 depending on the quantity of resected bone measured on the CT scan: 138 type A were partial vertebrectomies including costotransversectomy 139 and/or less than $25 \%$ VB resection, type B were partial vertebrectomies 140 including pedicle resection and/or facetect omy and/or less than 50\% VB 141 resection, and type Cwere partial vertebrectomies including more than $14250 \%$ VB resection. The a mount of resected VB was measured on a single 143 axial section of the immediate postoperative CT scan. We chose 144 systematically the single axial section showing the most extensive 145 resection of the VB. The vertebra with the most important resection was 146 chosen in case of multiple vertebral resection. Two composite groups 147 were al so created: a 1 ow-risk group of deformity, including group A and 148 group $B_{n<3}$, and a high-risk group including group $B_{n>=3}$ and group C. 149 Operative time length, blood loss volume and hospital length of stay 
150 were recorded. Each patient had a long-term clinical and radiological 151 follow up with spine CT scans and spine X-rays. The end-point of the 152 follow-up was at the time of the 1 ast X-ray retrieved from medical 153 records, or at the time of the second surgery for spine stabilization if 154 needed. The need for a second surgery was decided by the spine surgeon 155 and after a multidisciplinary consultation. Reoperation for 156 stabilization was decided according to importance of the progressive 157 spine defor mit y, back pain, performance stat us, operabil it y and patient 158 demand. Coronal Cobb angle (CCA), sagit tal Cobb angle at the edge of 159 the resection (SCAEOR), T1-T12 sagit tal Cobb angle (SCAT1-T12) were 160 reported immediately after surgery and at the end of the follow-up 161 (Figure 5). The differ ence between immediat e post oper at ive angles and the 162 late postoperative angles was then reported and compared between each vertebral resection group and according to the number of resected vertebrae. We also provide a qualitative analysis concerning the risk factors of a sagit tal deformit y over $5^{\circ}$ and $10^{\circ}$.

\section{St at istical analysis:}

168 We used Student's $t$-tests for spine angles analyses. The distribution of categorical variables 169 was compared with Fisher's exact test. All tests were two-sided and a p-value of $\leq 0.05$ was 170 considered to be statistically significant. Statistical analyses were performed using Statview 171 version 5.0 software (SAS Institute, Cary, NC, USA).

\section{Results:}

174 Eighteen patients were included. The median age was 60 years-old (range 175 46-81 years-old). Demographic and int $\mathrm{r}$ a oper at ive dat a are summarized in 
176 Table 2. WBB st a ging and SINS a r e r eport ed in Table 3. The t u mor hist ol ogy

177 was adenocarcinoma in 11 patients, squamous cell carcinoma in 5

178 patients, and undeter mined or other NSCLC in 2 patients. The average

179 blood 1 oss was $1614 \mathrm{ml}(200-4500 \mathrm{ml})$ and average operative 1 ength was 180390 minutes ( $\mathrm{r}$ a nge $140-650 \mathrm{~min}$ ). The average hospit al $1 \mathrm{ength}$ of stay was 181 days (range 5-37 days). No patient suffered from a serious 182 complication within the 30 days following the surgery. Acerebrospinal 183 fluid leak due to a dural tear occurred in one patient. Three patients 184 underwent type A vertebral resection (Group A), fourteen patients 185 underwent type B vertebral resection (Group B) and one patient 186 underwent type C vertebral resection (Group C). Among group B, five 187 patients had less than 3 resected vertebrae $\left(\right.$ Group $\left.B_{n}<3\right)$ and nine 188 patients had 3 or more resected vertebrae (Group $B_{n>=3}$ ). The overall 189 average number of resected vertebrae was 2,8 (range, 1-5) from 1evel T1 190 to T9. The median overall follow-up was 27 months (range 2-109). A 191 second surgical procedure for posterior spinal stabil izat ion was needed 192 for 4 patients (median delay was 8,5 months, range 2-18 months). Among 193 these 4 patients, 3 were re-operated because of back pain and progressive 194 deformity (angles for these patients were reported from preoperative X195 rays, and reported in the Table 4). Al 1 of them had good performance 196 status without progression of their disease. The fourth reoperated 197 patient received emergency surgery for decompression and st abil ization 1985 months after en bloc resection because of local tumor recurrence 199 revealed by a spinal cord compression. Among the fourteen other 200 patients, three patients died respectively 5 months, 6 months and 34 
201 months after surgery because of the progression of their cancer. Among

202 the remaining patients $(n=11)$, the median follow-up was 36 months (range 203 10-109). The variation of angles between immediate and late 204 postoperative assessment by specimen and for each groups are reported 205 in Table 4 and Table 5. Since only one patient was in the group C, we did not 206 perform statistical analysis with this subgroupalone. There was no 207 statistical difference on the sagittal or coronal balance between 208 group A and group B (Table 6). Wit hin the group B, resection of three 209 vertebrae or more trended to be associated with a higher risk of 210 sagit tal deformit y, even if the stat istical significance was not reached 211 wit h p=0,061 (SCA $\mathrm{EOR})$ and $\mathrm{p}=0,066\left(\mathrm{SCA}_{\mathrm{T} 1-\mathrm{T} 12}\right)$. Among the composit e groups, 212 the high-risk group showed significantly more sagit tal deformit y at the 213 end of the follow-up $(\mathrm{p}=0,01)$ (Table 6). We then made a categorical 214 analysis of which patient s had a progression of the sagit tal ky phosis of 215 more than $5^{\circ}$ and more than $10^{\circ}$. We confirmed that the high-risk group 216 was significantly associated with a worsening of the local and 217 regional kyphosis $(\mathrm{p}=0.01$ and $\mathrm{p}=0.004$, $\mathrm{r}$ espect ivel $\mathrm{y})$ whereas the 1 ow $-\mathrm{r}$ isk 218 group was not (Table 7). This trend showing a threshold in term of 219 sagittal balance when more than 3 vertebras were resected was 220 supported by our clinical experience: within the four patient $\mathrm{s}$ who 221 needed additional spinal stabilization, $t$ hree patient $\mathrm{s}$ were from group $222 B_{n}>=3$ and one of them was from group $C$, all of them belonging to the 223 high-r isk group.

225 Discussion: 
227 Preoperative status, assessment and staging of the disease

228 The management of BPCIS has evolved through the last decade. Tumors 229 with an invasion of the spine have long been considered as inoperable 230 and fatal ${ }^{5}$. An appropriate staging with a careful assessment of the 231 oncologic status prior to the surgery is essential to choose between 232 therapeutic options. Actually, an incomplete tumoral resection is 233 associated with a poorer oncologic outcome ${ }^{6,16}$. The Tumor, Node and 234 Metastasis classification makes chest wall involvement at least grade 235 T3 and VB involvement grade ${ }^{T} 4^{17}$. Preoperative evaluation of the 236 mediastinum with CT, MRI, posit ron emission tomography (PET) and/or 237 mediastinoscopy are required to determine lymph nodes invasion and 238 metastatic status before any curative surgery attempt. The role of 239 preoperative $\mathrm{r}$ adiotherapy and chemotherapy is widely supported in the 2401 it erature $5,6,10,18-20$. Potential benefits are the decrease in the size of 241 the tumor, the improved resectabil it y and a lower dissemination $r$ at e of 242 the tumor during surgery ${ }^{10}$. Various classifications about primary and 243 secondary bone tumors are provided in the 1 it erature. The aim of these 244 classifications is to help the surgeon in planning the most appropriate 245 tumoral resection in spinal tumors. The WBB staging ${ }^{13}$ were reported to 246 describe with more accuracy the characteristics of our cohort, even if 247 the relevance of this classification is not evaluated for PBCIS. In our 248 study,the local extension often came from the junction between the rib 249 and the VB by contiguity invasion, explaining why the WBB sector was 
250

251 SINS was developed by Fisher et al ${ }^{14}$ to define neoplastic-induced

252 instabil it y of the spine. The SINS was also quite homogenous due to 253 contiguity invasion of the VB: involvement of spinal posterior elements 254 was always unilateral (score $=1)$, without VB collapse (score 0 or 1 ), 255 and without spinal alignment abnormal it ies or deformit y (score $=0)$.

256

257 Surgical techniques

258 Different surgical techniques have been described for lung cancers 259 invading the spine. Intralesional resection was studied by several 260 authors like Bolton et al ${ }^{21}$ who reviewed two case-series of 17 patients 261 and 39 patient $\mathrm{s}$ with NSCLC invading the spine, or Bilsky et al ${ }^{22}$ who al so 262 reported 42 intralesional approach with a combined two-staged 263 procedure (posterolateral approach and midline posterior approach). 264 Grunenwald et al ${ }^{6}$ reported a 19-patients study of superior and non265 superior sulcus tumors invading the spine treated with en bloc surgical 266 technique. Fadel et ${ }^{20}$ and Collaud et al ${ }^{16}$ also performed en bloc 267 resection technique in a 54-patients study (although 17 pat ients were 268 concerned with hemivertebrectomies) and in a 48-patients study 269 respectively, both with excellent overall survival rates. Rates of 270 local and distant recurrence seem similar between these different 271 methods, whether the en bloc resection or the intralesional technique 272 was performed. However, more recent reports favour en bloc resection 273 through less invasive procedures: Stoker et al ${ }^{23}$ reported a case-series 
274 of 8 en bloc resection with a sequential video-assisted thoracoscopic 275 surgery combined with posterior spinal resection, showing a lower 276 estimated blood loss quant it y and lower length of the hospital stay. 277 Tomit a et al ${ }^{24}$ and Jain et al ${ }^{15}$ described a single-st age posterior midline 278 approach for en bloc resection with circumferential spinal 279 stabilization. This a pproach offers a one-st age definit ive resection and 280 stabilization. Overall comparison of previously cited st udies tends to 281 show a better rate of complete resection with en bloc resection 282 techniques ${ }^{6,10,16,25}$. In our study, all patients underwent a single-stage 283 procedure through a posterolateral thoracotomy with an extended 284 incision over the posterior midline to expose the spine. When an ant er ior 285 cervico-thoracotomy was required due to anatomical consideration, no 286 second-stage was necessary because posterior spinal instrumentation 287 was not performed. All resections were performed with en bloc 288 technique without violating the edge of the tumors.

290 Survival status and perioperative morbidity and mortality

291 In most studies involving surgical treatment with vertebral resection, 292 the 5-year survival rate ranges between 10 and $61 \%{ }^{6,15,21,22}$. High rates of 293 postoperative morbidity or mortality $6,10,16,18,20,25$ makes surgical 294 management challenging for multidiscipl inary teams. Trying to reduce 295 operative time length and blood loss is a key point to improve 296 postoperative course. Various post operat ive compl icat ions are report ed 297 in the 1 it erature: bronchopleural fist ula, meningit is, at elect asis, acute 298 respiratory dist ress syndrome, hy povol emia, deep infect ion, compression 
299 fractureat the distal end of instrumentation, spinal device dislocat ion 300 or wound dehiscence ${ }^{23}$. Few reports take into consideration operative 301 blood loss and mean operative time. Stoker et al ${ }^{23}$ reported a mean 302 estimated blood loss of $813 \mathrm{~mL}$ for video-assisted thoracoscopic 303 thoracotomy combined to posterior spinal approach, and an estimated 304 blood loss of $1250 \mathrm{~mL}$ concerning opened thoracotomies. In our study, 305 the mean operative time reported was 367 minutes (thoracoscopic 306 thoracotomy) and 518 minutes (opened thoracotomy). Anraku et al 10 307 reported an analysis over 23 consecutive pat ients with systematic spinal 308 instrumentation. Nine patients underwent a one-stage operation and 14 309 underwent a two-stage operation. The average number of vertebrae 310 resected were 3,5 (st aged surgery) and 2,5 (1-st age surgery), which seems 311 to be comparable to the average number of vertebrae resected in our 312 study $(n=2,8)$. Mean operative time was 12,3 hours and 19,3 hours 313 respectively wit hean blood 1 oss during surgery of $2700 \mathrm{~mL}$ and $4000 \mathrm{~mL}$ 314 respectively. Median duration of hospitalization was 23 days and 2 315 patients $(8,7 \%)$ died during immediate postoperative course because of 316 pneumonia and bronchopleural fistula. In our study, we report lower 317 operative blood loss (mea n bleeding was $1614 \mathrm{~mL}$ ), lower operat ive time 318 (mean operat ive time was 390 minutes), lower duration of hospit alizat ion 319 (median was 13 days) and no post operative deat h.

\section{Spinal instrumentation and spine deformity}

322 There is no consensus about spinal instrumentation after partial 323 vertebrectomy for PBCIS. Bolton et al ${ }^{21}$ performed instrumentation 
324 only in case of total vertebrectomy $(n=15)$ excepted for the case of one 325 patient who underwent resection of all posterior elements over two 326 adjacent levels. However, most authors perform at least anterior or 327 posterior instrumentation, or even both anterior and posterior 328 instrumentation in case of pre-existent spinal deformity or multilevel 329 vertebral involvement ${ }^{26}$. From our experience, the outcomes in terms of 330 spinal deformity depend on the type of the vertebral resection and on 331 the number of adjacent resections. It is commonly admit ted that type A 332 resections do not require complementary spinal instrumentation 333 whereas type B resections require posterior inst $r$ ument at ion and ype C 334 resections require both anterior and posterior instrumentation ${ }^{15,27}$. 335 While we found this postulate acceptable for type A and type C 336 resection, we made the hypothesis that type B resection groupdoes not 337 require complementary spinal instrumentation in any cases. To our 338 knowledge, no vertebral resection threshold was previously reported 339 in the literature to justify spinal instrumentation. There is also a 340 paucity of the 1 it erature concerning deformity issues and outcome 341 concerning this population. Our results suggest that type A and type B 342 with less than 3 resected vertebrae (low-risk group) are not subject to 343 important sagit al and coronal deformity even after a late follow-up 344 while type B on more than three vertebrae and type C resection are 345 more likely to present a sagittal deformity. Statistical difference 346 between $10 \mathrm{w} \mathrm{risk}$ and high $\mathrm{r}$ isk groups was only reached in term of 347 sagittal deformity. This suggesting that a systematic stabilization 348 might be avoided in the low-risk group, thus limiting the surgical 
morbidity associated with these procedures. However, our study

350 clearly suffers froma 1 ack of stat ist ical power. Further investigations

351 wit h larger controlled case-series are needed to confir m theseresults.

352

353

354

355

356

357

358

359

360

361

362

363

364

365

366

367

368

369

370

371

372 described: A (extraosseous sof tissues), B (intraosseous superficial), C

373 (intraosseous deep), D (extraosseous extradural), E (extraosseous

374 intradural) and F (Vertebral artery involvement). 
377 Specimen of an en bloc resected tumor involving 1 ung, chest wall and 378 threevertebrae.

379

380

381

382

383

384

\section{Figure $3($ COLOR)}

Different types of partial vertebrectomies: type A partial vertebrectomy includes costotransversectomy and/or less than $25 \%$ vertebral body resection, type $B$ partial vertebrectomy includes pedicle resection and/or facetectomy and/or less than 50\% vertebral body resection, and type C partial vertebrectomy includes more than $50 \%$ vertebral body resection.

\section{Figure 4}

CT scan axial section reconstructions showing Type A (A), Type B (B) and Type C (C) partial vert ebrectomies.

\section{Figure $5($ COLOR)}

Thoracic spine represented on sagit tal plane (left) and on coronal plane (right). Yellow marks illustrate T1-T12 sagittal Cobb angle $\left(\mathrm{SCA}_{\mathrm{T} 1-\mathrm{T} 12}\right), \mathrm{red}$ marks il 1 ustrate sagit tal Cobb angle at the edge of the resection (SCAEOR) and blue marks il lust rate coronal Cobb angle (CCA).

\section{$\underline{\text { Tables }}$}

\section{Table 1: The Spine Instability Neoplastic Score (SINS)}


401

402

403

404

405

406

407

408

409

410

411

412

413

414

415

416

417

418

419

420

421

422

423

424

425

426

427

428

429

430

431

Table 2: Preoperative spinal invasion assessment: Weinstein, Boriani, Biagini (WBB) classification and Spine Instability Neoplastic Score (SINS).

Table 3: Characteristics of the surgical cohort

Table 4: Difference between immediate and late $\mathrm{CCA}, \mathrm{SCA}_{\mathrm{EOR}}, \mathrm{SCA}_{\mathrm{T1} 1 \mathrm{T12}}$ by specimen.

Table 5: Difference between immediate and late $\mathrm{CCA}, \mathrm{SCA}_{\mathrm{EOR}}, \mathrm{SCA}_{\mathrm{T1} 1 \mathrm{T12}}$ by subgroups.

Table 6: Comparison of spine deformity depending on type of vertebral resection

Table 7: Comparison of effectives with variation of the sagittal kyphosis over $5^{\circ}$ and over $10^{\circ}$

\section{$\underline{\text { References }}$}

1. Komaki R, Roth JA, Wal sh GL, Putnam JB Jr, Va por ciyan A, Lee JS, et a1. Out-come predictors for 143 patients with superior sulcus t umors treated by multidisciplinary approach at the Universit y of Texas MD Anderson Cancer Center. Int J Radiat Oncol Biol Phys. 2000;48:347-54.

2. Farray

$\mathrm{D}$

Mir kovic

$\mathrm{N}$

Al ba in

KS. Multimodalit ytherapyforstageIIInon-small-cell lung cancer. J $\mathrm{Cl}$ in Oncol . 2005;23:3257-69.

3. Pancoast HK. Superior pulmonary sulcus tumor: tumor characterized by pain, Horner's syndrome, destruction of bone and at rophy of hand muscles. JAMA 1932;99:1391-6.

4. Tobias JW. Sindrome a pico-costo-vertebral doloroso por tumor a pexiano: su valor diagnostico en el cancer primitvo pulmonary. Rev Med Lat in o Am. 1932;17:1522-56. 
432

433

434

435

436

437

438

439

440

441

442

443

444

445

446

447

448

449

450

451

452

453

454

455

456

5. St a mat is G, Djuric D, Eberhardt W, Pot t ken C, Zaboura G, Fechner S, et al. Post-operative morbidity and mortality after induction chemoradiotherapy for locally advanced lung cancer: an analysis of 350 operated patients. Eur J Cardiothorac Surg. 2002;22:292-7.

6. Gr unenwald DH, Mazel C, Gir ard P, Veronesi G, Spaggiari L, Gossot D, et a 1 .

Radical en bloc resection for lung cancer invading the spine. $J$ Thor a c Cardiovasc Surg. 2002;123:271-9.

7. Gandhi S, Walsh GL, Komaki R, Gokaslan ZL, Nesbit t JC, Put-nam JB Jr, et a l: A multidiscipl inary surgical approach to superior sulcus t umors wit h vertebral invasion. Ann Thorac Surg 68: 1778-1785, 1999

8. Mazel C, Grunenwald D, Laudrin P, Marmorat JL. Radical excision in the management of thoracic and cervicothoracic tumors involving the spine: results in

a ser ies of 36 cases. Spine. 2003;28:782-92; discussion 92.

9. Rusch VW, Gir oux DJ, Kraut MJ, Crowley J, Hazuka M, Wint on T, et al. Induction chemoradiation and surgical resection for superior sulcus non-small-cell lung carcinomas: long-term results of Sout hwest Oncology Group Trial 9416 (Int ergroup Trial 0160). J Cl in On c ol . 2007;25:313-8.

10. Anraku M, Waddell TK, de Perrot M, et al. Induction chemoradiotherapy facil it ates radical resection of T4 non-small cell lung cancer invading the spine. J Thorac Cardiovasc Surg 2009;137:441-447.e 1. 
11. Sartori F, Rea F, Calabro F, et al. Carcinoma of the superior pulmonary sulcus. Results of ir radiation and radical resection. J Thor ac Cardiovasc Surg 1992;104:679-83.

12. York JE, Wa 1 sh GL, Lang FF, Put nam JB, McCutcheon IE, Swisher SG, et al: Combined chest wall resection with vertebrec-tomy and spinal reconstruction for the treatment of Pancoast tumors. J Neur osurg 91 (1 Suppl):74-80, 1999

13. Bor iani S, Weinst ein JN, Biagini R, Primary bone $t$ umor s of the spine: Ter minol ogy and Surgical St aging. Spine. 1997 ;22(9):1036-1044

14. Fisher CG, Keynan O, Boyd MC, Dvor ak MF, The surgical management of primary tumors of the spine. Spine $2005 ; 30: 1899$ 1908

15. Ja in S, Sommer s E, Set zer M, Vr ion is F. Post er ior midl ine a ppr o a ch for single-stage en bloc resection and circumferential spinal stabilization for locally advanced Pancoast tumors: technical not e. J Neur o sur g Spine 2008;9:71-82.

16. Collaud S, Waddell TK, Yasufuku K, Pierre AF, MD, Darling GE, Cypel M, Ra mpersaud YR, Lew is SJ, Shepherd FA, Leighl NB, Cho J, Bezjak A, Sound Tsao M, Keshavjee S, de Perrot M, Long-Term Out come after En Bloc Resection of Non-Small-Cell Lung Cancer Invading the Pulmonary Sulcus and Spine J Thorac Oncol. 2013;8: $1538-1544$

17. Rami-Porta R, Bolejack V, Giroux DJ, Chansky K, Crowley J, Asamura $\mathrm{H}$, et al; International Association for the St udy of Lung Cancer Staging and Prognostic Factors Committee, Advisory Board Members and Participating Inst it utions. The IASLC Lung 
Cancer Staging Project: the new database to inform the eighth edit ion of the TNM classification of $1 \mathrm{ung}$ cancer. J Thorac Oncol. 2014;9:1618-24

18. Schir ren J, Donges T, Melzer M, Schönmayr R, Eber lein M, Böl ükbas S. En bloc resection of non-small-cell lung cancer invading the spine. Eur J Cardiothorac Surg 2011;40:647-654.

19. St a mat is G. Risks of neoadjuvant chemotherapy and radiation 490 ther a py. Thor a c Surg Cl in 2008;18:71-80.

20. Fadel E, Missenard G, Court C, et a l. Long-t er moutcomes of en bloc 492 resection of non-small cell lung cancer invading the thoracic in 1 et and spine. Ann Thor ac Surg 2011;92:1024-1030.

21. Bolt on WD, Rice DC, Goodyear A, et al. Superior sulcus tumors with 495 vertebral body involvement: a multimodal ity approach. J Thorac Car diova sc Surg 2009;137:1379-1387.

22. Bil sky MH, Vit a z TW, Bol and PJ, Bains MS, Rajar a ma n V, Rusch VW: 498 499 Surgical treatment of superior sulcus tumors with spinal and brachial plexus involvement. J Neur osurg 97 (3 Su ppl ): 301-309, 2002

23. St oker GE, Buchowski JM, Kelly MP, et al. Video-assisted 501 thoracoscopic surgery with posterior spinal reconstruction for the resection of upper lobe 1 ung tumors involving the spine. Spine $\mathbf{J}$ 2013;13:68-76.

504

24. To mit a K,Ka wa ha r a N,Baba H,Tsu chiy a H,Fujit a T,Tor ibat a ke Y: Tot a 1 505 en bloc spondylectomy. A new surgical technique for primary malignant vert ebral t umors. Spine 22:324-333, 1997 
al. En bloc partial vertebrectomy for lung cancer invading the spine after induction chemoradiotherapy. Eur J Cardiothorac Surg. 2007;31:788-90.

511

26. Gokaslan ZL, Walsh GL: "Trap door" exposure of the cervicothoracic junction, in Rengachary SS: Neurosurgical Oper at ive Color At las, Vol 8. Lebanon, NH: AANS Publ ic at ions, 1999, pp 253-260

27. Zair i F, Sunna T, Liberman M, Boubez G, Wang Z, Shedid D. Single Posterior Approach for En-Bl oc Resection and Stabilization for Locally Advanced Pancoast Tumors Involving the Spine: Single 


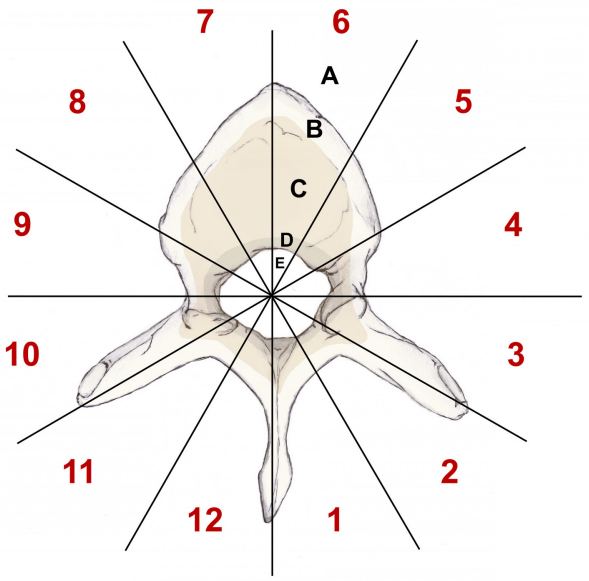




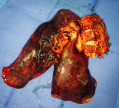




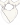

res.

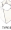

ne 


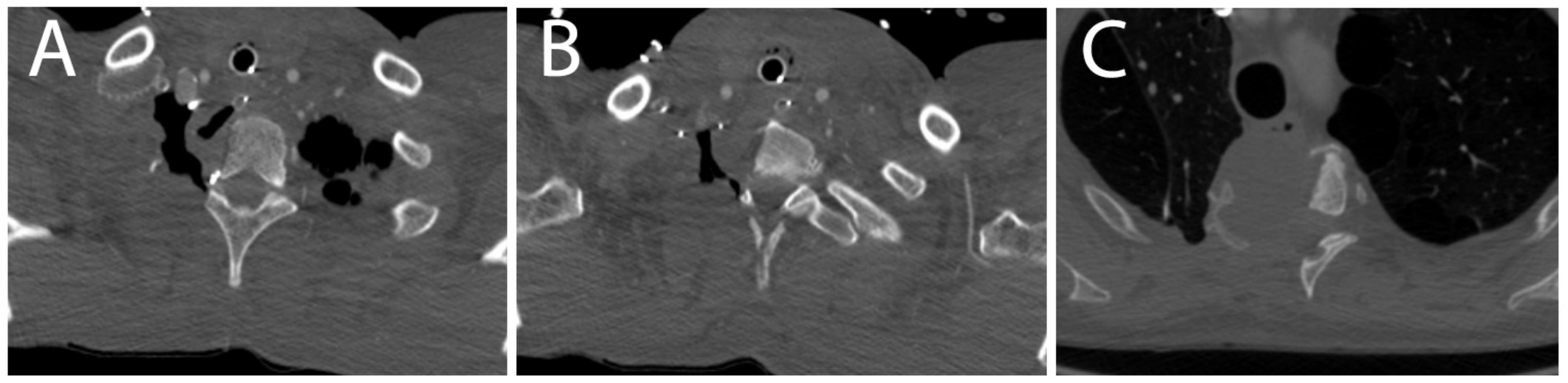



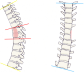


\begin{tabular}{|c|c|}
\hline Element of SINS & Score \\
\hline \multicolumn{2}{|l|}{ Location } \\
\hline Junct ion a 1 (o c ciput-C2, C7-T2, T11-L1, L5-S1) & 3 \\
\hline Mobil e spine (C3-C6, L2-L4) & 2 \\
\hline Semi-r ig id (T3-T10) & 1 \\
\hline Rig id (S2-S5) & 0 \\
\hline \multicolumn{2}{|l|}{ Pain relief with recumbency and/or pain with movement } \\
\hline Yes & 3 \\
\hline No (occasional pain but not mechanical) & 1 \\
\hline Pa in free lesion & 0 \\
\hline \multicolumn{2}{|l|}{ Bone lesion } \\
\hline Lyt ic & 2 \\
\hline Mixed (l yt ic/bl a st ic) & 1 \\
\hline Bl ast ic & 0 \\
\hline \multicolumn{2}{|l|}{ Radiographic spinal alignment } \\
\hline Subluxation/translation present & 4 \\
\hline De novo defor mit y (kyphosis/scol iosis) & 2 \\
\hline Nor mal al ignment & 0 \\
\hline \multicolumn{2}{|l|}{ Vertebral body collapse } \\
\hline$>50 \%$ c oll a pse & 3 \\
\hline$<50 \%$ c olla pse & 2 \\
\hline No collapse wit $h>50 \%$ body involved & 1 \\
\hline None of above & 0 \\
\hline \multicolumn{2}{|l|}{ Posterolateral involvement of the spinal elements } \\
\hline Bil a t er a 1 & 3 \\
\hline Unil a t er a 1 & 1 \\
\hline None of the above & 0 \\
\hline
\end{tabular}

Table 1: The Spine Instability Neoplastic Score (SINS). 


\begin{tabular}{|c|c|c|}
\hline \multicolumn{2}{|c|}{ Variables } & n $(\%)$ \\
\hline Gender & $\begin{array}{r}\text { Female } \\
\text { Male }\end{array}$ & $\begin{array}{c}4(22) \\
14(78)\end{array}$ \\
\hline Hist ol og $\mathrm{y}$ & $\begin{array}{r}\text { Adenocarcinoma } \\
\text { Squa mouscel } 1 \\
\text { carcinoma } \\
\text { other }\end{array}$ & $\begin{array}{l}11(61) \\
5(28) \\
2(11)\end{array}$ \\
\hline $\begin{array}{c}\text { Type of vertebral } \\
\text { resection }\end{array}$ & $\begin{array}{l}\text { Type A } \\
\text { Ty pe B } \\
\text { Type C }\end{array}$ & $\begin{array}{c}3(17) \\
14(78) \\
1(5)\end{array}$ \\
\hline $\begin{array}{c}\text { Number of vertebral } \\
\text { resection }\end{array}$ & $\begin{array}{r}\text { One } \\
\text { Two } \\
\text { Three } \\
\text { Four } \\
\text { Five }\end{array}$ & $\begin{array}{l}0 \\
9 \\
6 \\
2 \\
1\end{array}$ \\
\hline $\begin{array}{c}\text { Level of vertebral } \\
\text { resection }\end{array}$ & $\begin{array}{l}\text { T1 } \\
\text { T2 } \\
\text { T3 } \\
\text { T4 } \\
\text { T5 } \\
\text { T6 } \\
\text { T7 } \\
\text { T8 } \\
\text { T9 }\end{array}$ & $\begin{array}{c}4 \\
9 \\
11 \\
9 \\
5 \\
4 \\
2 \\
3 \\
2\end{array}$ \\
\hline Residual margin & $\begin{array}{l}\text { R0 } \\
\text { R1 }\end{array}$ & $\begin{array}{c}16(89) \\
2(11)\end{array}$ \\
\hline Bl ood loss & $\begin{array}{r}\text { Median (ml ) } \\
\text { St a ndard deviation } \\
(\mathrm{ml}) \\
>1000 \mathrm{ml} \\
1000-2000 \mathrm{ml} \\
>2000 \mathrm{ml} \\
\end{array}$ & $\begin{array}{c}1400 \\
1157 \\
\\
5 \\
7 \\
6\end{array}$ \\
\hline Hospital length of stay & $\begin{array}{r}\text { Median (days) } \\
\text { St andarddeviation } \\
\text { (days) } \\
<10 \text { days } \\
10-20 \text { days } \\
>20 \text { days }\end{array}$ & $\begin{array}{c}11 \\
7,7 \\
7(39) \\
9(50) \\
2(11)\end{array}$ \\
\hline Survival & $\begin{array}{r}\text { Survival } \\
\text { Death } \\
\text { 12-months survival } \\
\text { rate }(\%)\end{array}$ & $\begin{array}{c}15(83) \\
3(17) \\
86\end{array}$ \\
\hline $\begin{array}{c}\text { Second surgery for } \\
\text { spinal instrument at ion }\end{array}$ & $\begin{array}{r}\text { Second surgery } \\
\text { No second surgery }\end{array}$ & $\begin{array}{l}4(22) \\
14(78)\end{array}$ \\
\hline
\end{tabular}

Table 2: Characteristics of the surgical cohort 


\begin{tabular}{|c|c|c|c|}
\hline \multirow{2}{*}{ Case } & \multicolumn{2}{|c|}{$\begin{array}{c}\text { Weinstein, Boriani, Biagnini (WBB) } \\
\text { classification }\end{array}$} & $\begin{array}{c}\text { Spine Instability } \\
\text { Neoplastic Score } \\
\text { (SINS) }\end{array}$ \\
\cline { 2 - 3 } & WBB Sector & WBB Level & 7 \\
\hline 1 & $7-8$ & A-B & 4 \\
\hline 2 & $5-6$ & A-C & 7 \\
\hline 3 & $5-7$ & A-B & 11 \\
\hline 4 & $7-10$ & A-C & 7 \\
\hline 5 & $4-6$ & A-B & 8 \\
\hline 6 & $8-10$ & A-C & 9 \\
\hline 7 & $8-11$ & A-B & 9 \\
\hline 8 & $8-10$ & A-D & 9 \\
\hline 9 & $8-10$ & A-C & 7 \\
\hline 10 & $7-9$ & A-C & 9 \\
\hline 11 & $4-7$ & A-C & 7 \\
\hline 12 & $8-10$ & A-C & 9 \\
\hline 13 & $3-7$ & A-C & 9 \\
\hline 14 & $7-10$ & A-D & 9 \\
\hline 15 & $3-5$ & A-C & 7 \\
\hline 16 & $3-4$ & A-C & 7 \\
\hline 17 & $6-9$ & A-B & 10 \\
\hline 18 & $6-11$ & A-D & \\
\hline
\end{tabular}

Table 3: Preoperative spinal invasion assessment: Weinstein, Boriani, Biagini (WBB) classification and Spine Instability Neoplastic Score (SINS). 


\begin{tabular}{|c|c|c|c|c|c|}
\hline Case & $\begin{array}{c}\text { Vertebral } \\
\text { Resection Type }\end{array}$ & $\begin{array}{c}\text { Difference between immediate and } \\
\text { late } \mathrm{CCA}\left(^{\circ}\right)\end{array}$ & $\begin{array}{c}\text { Difference between immediate } \\
\text { and late SCAEOR }\left(^{\circ}\right)\end{array}$ & $\begin{array}{c}\text { Difference between immediate } \\
\text { and late } \text { SCAT1-T12 }^{\left.{ }^{\circ}\right)}\end{array}$ & $\begin{array}{c}\text { Later } \\
\text { instrumented } \\
\text { stabilization }\end{array}$ \\
\hline 1 & $\mathrm{~A}$ & 0 & 0 & 2 & no \\
\hline 2 & $\mathrm{~A}$ & 0 & 0 & 3 & no \\
\hline 3 & A & 3 & 1 & 2 & no \\
\hline 4 & B & 8 & 21 & 23 & yes \\
\hline 5 & B & 2 & 1 & 2 & no \\
\hline 6 & B & 0 & 6 & 10 & no \\
\hline 7 & B & 16 & 23 & 26 & yes \\
\hline 8 & B & 4 & 16 & 16 & no \\
\hline 9 & B & 3 & 3 & 6 & no \\
\hline 10 & B & 1 & 0 & 2 & no \\
\hline 11 & B & 7 & 3 & 4 & no \\
\hline 12 & B & 3 & 0 & 3 & no \\
\hline 13 & B & 0 & 26 & 30 & no \\
\hline 14 & B & 15 & 52 & 58 & yes \\
\hline 15 & B & 6 & 3 & 4 & no \\
\hline 16 & B & 3 & 1 & 2 & no \\
\hline 17 & B & 0 & 0 & 0 & no \\
\hline 18 & $\mathrm{C}$ & 16 & 17 & 25 & yes \\
\hline
\end{tabular}

Table 4: Difference between immediate and late CCA, SCAEOR, SCA 1 1-T12 by specimen. 


\begin{tabular}{|c|c|c|c|}
\hline $\begin{array}{c}\text { Vertebral resection } \\
\text { subgroups }\end{array}$ & $\begin{array}{c}\text { Difference between immediate } \\
\text { and late CCA }\left(^{\circ}\right)\end{array}$ & $\begin{array}{c}\text { Difference between immediate } \\
\text { and late SCAEOR }\left(^{\circ}\right)\end{array}$ & $\begin{array}{c}\text { Difference between immediate } \\
\text { and late SCAT1-T12 }\left(^{\circ}\right)\end{array}$ \\
\hline $\begin{array}{c}\text { Group A } \\
\text { mean }\end{array}$ & 1 & 0 & 2 \\
median & 0 & 0 & 2 \\
\hline Group B & 5 & 11 & 13 \\
mean & 3 & 4 & 5 \\
median & 3 & 1 & 2 \\
Group $\mathrm{B}_{\mathrm{n}<3}$ & 3 & 0 & 3 \\
mean & & 16 & 19 \\
\hline median & 6 & 16 & 16 \\
\hline
\end{tabular}

Table 5: Difference between immediate and late CCA, SCAEOR, SCAT1-T12 by subgroups. 


\begin{tabular}{|c|c|c|c|}
\hline Variables & $\mathbf{n}$ & p-value & 95\% Confidence interval \\
\hline $\begin{array}{r}\text { Group A vs Group B } \\
\begin{array}{r}\text { Coronal deformity: CCA } \\
\text { Sagittal deformity: SCAEOR }\end{array} \\
\text { Sagittal deformity: SCAT1-T12 }\end{array}$ & 3 vs 14 & $\begin{array}{l}0.225 \\
0.235 \\
0.286\end{array}$ & $\begin{array}{l}-10.300 ; 2.629 \\
-29.857 ; 7.953 \\
-31.439 ; 9.962\end{array}$ \\
\hline 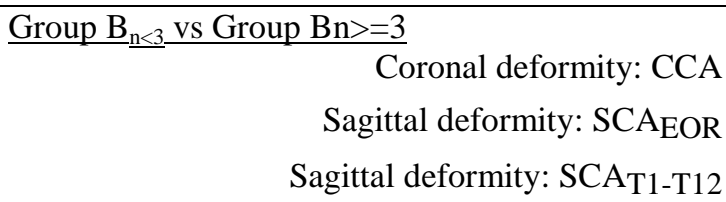 & 5 vs 9 & $\begin{array}{l}0.628 \\
0.061 \\
0.066\end{array}$ & $\begin{array}{c}-7.557 ; 4.749 \\
-32.192 ; 0.903 \\
-34.520 ; 1.320\end{array}$ \\
\hline $\begin{array}{r}\text { Low-risk group vs High-risk group } \\
\text { Coronal deformity: CCA } \\
\text { Sagittal deformity: SCAEOR } \\
\text { Sagittal deformity: SCA } 1 \text { T1-T12 }\end{array}$ & 8 vs 10 & $\begin{array}{l}0.092 \\
\mathbf{0 . 0 1 0} \\
\mathbf{0 . 0 0 7}\end{array}$ & $\begin{array}{c}-9.566 ; 0.816 \\
-28.726 ;-4.523 \\
-31.982 ;-5.934\end{array}$ \\
\hline
\end{tabular}

Table 6: Comparison of spine deformity depending on type of vertebral resection 


\begin{tabular}{|c|c|c|c|}
\hline Variables & n & SCAEOR $^{\text {Sp-values })^{*}}$ & SCAT1-T12(p-values)* \\
\hline Kyphosis progression over 5 ${ }^{\circ}$ in sagittal plane & & $\mathbf{0 . 0 3 1}$ & $\mathbf{0 . 0 3 1}$ \\
Group Bn<3 versus Group Bn>=3 & 5 vs 9 & $\mathbf{0 . 0 2 5}$ & $\mathbf{0 . 0 0 4}$ \\
Low-risk group vs High-risk group & 8 vs 10 & 0.086 & $\mathbf{0 . 0 3 1}$ \\
\hline Gyphosis progression over $10^{\circ}$ in sagittal plane & & $\mathbf{0 . 0 1 3}$ & $\mathbf{0 . 0 0 4}$ \\
Low-risk group vs High-risk group & 8 vs 10 & & \\
\hline
\end{tabular}

*Fisher exact test

Table 7: Comparison of effectives with variation of the sagittal kyphosis over $5^{\circ}$ and over $10^{\circ}$. 